\title{
RADIO AND TELEVISION IN THE NAZI MEDIA SYSTEM
}

\author{
Vladimir Barović \\ University of Novi Sad, Faculty of Philosophy in Novi Sad, \\ Department of Media Studies
}

This paper analyses the Nazi media system with special emphasis on electronic media. In particular, radio is seen as the primary means by which the Nazi propaganda deliberately indoctrinated the German people. It analyses the role and importance of Joseph Goebbels in the creation, expansion and development of a complex system of propaganda in the Third Reich. The paper evaluated the first beginnings of television in Germany where the Nazis attached special attention to it as a medium that had a great promotional opportunity.

Key words: Nazism, the electronic media, Goebbels, propaganda

\section{Introduction}

Nazism as a totalitarian movement very well understood the power of electronic media at the beginning of the thirties of last century when it was in its infancy and Joseph Goebbels, the first man of Hitler's propaganda in the German media was made a torchbearer of the Nazi regime. Although the Nazis in terms of professional journalistic ethics may be found at fault with many things, it is an inevitable fact that they very well understood the power and influence of media. Their journalistic "spiritus movens" certainly was Joseph Goebbels, who in journalistic circles was known by often used pseudonym "Dr G" as mentioned in the below articles and columns. Nazism is widely known for great brutality and the death of millions of innocent people but the system was intolerant, had a very complex and an elaborate media scene.

In Hitler's state, media were the controllers of the heart and minds of citizens that had to be kept in submission and obedience, with a well-known dictator, and more open methods of terror such as the Gestapo and the SS. The refined method was brought to perfection by Goebbels, which is found in a radio speech to directors of companies in 1939 , in which he addressed them with following words that capture the very essence of the Nazi media system: "This is the secret of propaganda: the one who wants to include propaganda, completely saturate the ideas, cannot see that it is permeated. It is understood itself to propaganda aims, but the intention has to be so smart and cleverly hidden, to whom the intention to be fulfilled, it does not feel" (Knopp, 2009).

*PhD Vladimir Barović, Assistant Professor, barovic@neobee.net 


\section{A hundred times repeated lie is the truth}

The first man of the media machine of the Third Reich, Joseph Goebbels in 1926 began with the ascension on the party ladder, because then he became a provincial leader, gauleither, in Berlin - Brandenburg. As he showed great ability in propaganda, Goebbels was appointed by Hitler the supreme leader of the party propaganda in 1929 (Reichspropagandaleiter), and in 1932 he organized two pre-election campaigns for the parliament and the presidential elections. Goebbels was an expert in propaganda techniques and wrote the ten commandments of "good propaganda", the first codified and defined manual manipulation of the media. He was an excellent speaker and his fiery addresses to the mass audience had a great mobilizing effect after one speech, boasting as his associates said, "If I told men to jump from the third floor - they would do it" (Knopp, 2009).

In March 1933, Goebbels was appointed Minister of Propaganda of the Third Reich and in public administration and all pores of social life, he introduced the so-called equalization Gleichschaltung. By this system, all media were put under state supervision and newspapers, radio and film had to adhere in their work with Nazi wishes. National-socialist ideology would not enter the German masses no sooner than the breakthrough of Goebbels' information made through all these media, including television, which was in its infancy. This smallish, dark-haired, sincere anti-Semite used toxic language attributed to the motto which reads: "A lie repeated often enough becomes the truth".

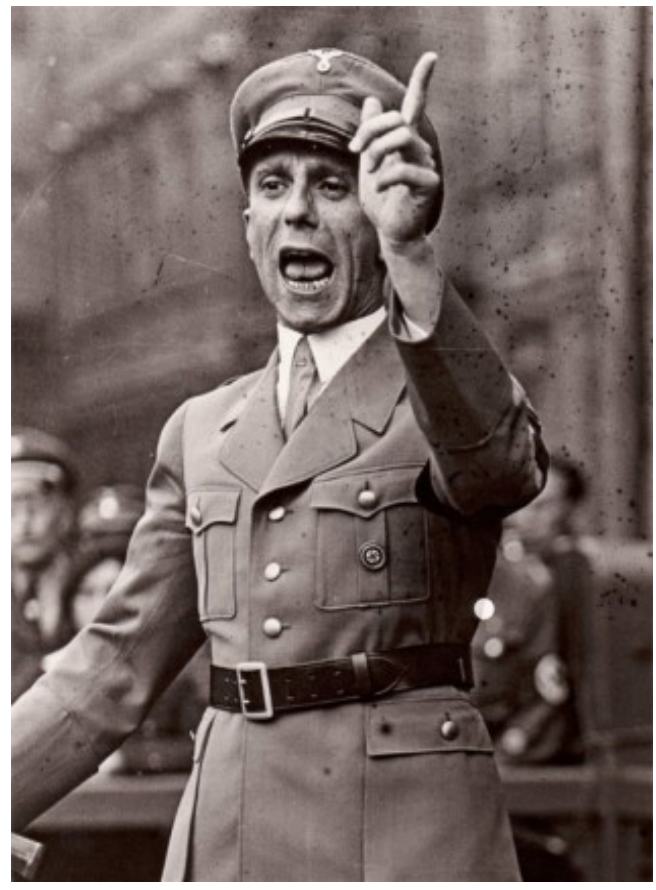

Reichspropagandaleiter Joseph Goebbels 
Goebbels introduced a rule that every editor in Germany had to be "racially and politically clean" because of the Press Law of 1933. The journalist declared public interest work, and all the editors had to be of German nationality, "of Aryan descent and not allowed to be married to a non-Aryan partner" (Kershaw, 2004). Otto Dietrich became the Head of the State Press and Goebbels' assistant in the Ministry of Propaganda, who was seduced by his superior's terror among German journalists.

Famous American journalist, a correspondent of many radio stations who worked in Germany from 1930 to 1941, William Shirer wrote about the Nazi law on the media, "Article 14 of the law, ordered the editors of newspapers not to publish what the public would perceive as a mistake, not to mix personal interests with the public one, not to weaken the strength of the German Reich, outwardly or inwardly, the common will of the German people, defence of the country, its culture and economy ... and not to insult the honour and dignity of the country. That would be the article, and the law was in effect before 1933, pulled behind a ban on all publications in Nazi Germany"- concluded Shirer (Shirer, 1977). The same rules to more severe were applied for the electronic media or radio which by the concepts in the Third Reich was the most powerful media tool that is an important part in the machinery of a totalitarian system.

\section{Radio worked as a sword and shield of Nazism}

Radio in the early thirties of the last century was a new means of information in the expansion, which Goebbels understood as a high technological achievement that allowed any German hear Hitler speak at the same time, regardless of the fact that they were hundreds of miles away from the place of the party rally. Head of Nazi propaganda saw the media as the most important tool in the modern scale propaganda tool, and his ministry formed a Department for radio and the Chamber of radio (the President was Horst Dressler - Anders), which monitored the broadcast of all stations in the country. Head of radio propaganda in Goebbels' ministry was Hans Fritsch, whose show "Hans Fritsch Speaks" had an enormous popularity of 16 million listeners. He wrote the best radio comments in the Third Reich and was appointed to interpret on the national network the actions and attitudes of political parties and governments on major issues. Fritsch was inspired by the ideology of "My struggle", listeners talked about the alleged worldwide Jewish conspiracy to destroy democracy, plutocratic national power, Bolshevik danger, "the benefits" of "fuhrerprincip" and its alleged benefits for the country and the nation. Before the war, he talked about Hitler's genius, which, as he explained to the audience, no one in German history had reached. The first victory in the West was bombastically published on the radio by Fritsch, and later he raised the morale which had decreased due to defeat and all the more weakened faith in the "final victory" which was slowly but surely coming to an end. Although there were a lot of Nazi-minded journalists who poured insults at the expense of Jews and opponents of Hitler's regime, Fritsch was the editor of "Der Stürmer". Julius Streicher was one of the few propagandists who because of his activities was found guilty in court in Nuremberg.

Radio program in the Third Reich was uniform and that is a characteristic of totalitarian regimes, not so much the creative broadcasting where the listening audience 
Radio and television in the nazi media system

in silence of their living rooms among their family criticized annoying radio programs. Often they are German citizens listened to the radio station but from the beginning of war to become the forbidden fruit that could be very dangerous, because for these listener adventures easy going to a concentration camp. Radio was still the most effective means of advertising that successfully shaped the German public opinion and, being the fastest medium (such as today), Hitler used it plenty, especially during the race in 1932 when the council with Goebbels was not played in cities which did not own transmitters. Fuhrer's fiery speeches preceded the introduction, skilfully designed by Goebbels, by a radio reporter who prepared the audience for what Hitler himself was involved in as a propagandist, presented as the main message.

Realizing that for effective advertising it is important to launch short, clear messages that are easy to remember, Goebbels sent the following slogans in the ether: "One nation, one state, one leader", "The Jews are our misfortune!", "You are nothing, the people is everything". When the radio slogans and credible reports that they were ordinary news convinced the German audience of the correctness of Nazi policy, it was almost impossible to make public opinion different from the regime. On this phenomenon in the Third Reich, Shirer writes: "It is obvious that the parrots (citizens of Germany, V. B) repeated the nonsense they had heard on the radio or read in the newspaper. Sometimes I was tempted to tell them it, and when I did so, they looked at me tensely in disbelief or would shut-up astonished, like I blasphemed God. I am convinced that the vain attempt to make contact with the brains that are crooked to the facts of life is what Hitler and Goebbels, with his cynical contempt for the truth, intended" (Shirer, 1977).

The great possibilities of radio transmitters coming out of the German feuilleton entire print readers who explained the great achievements of the media. Thus, in the German magazine "Signal" we can read the article by Ludwig Kapeller, under suggestive title "Here says Europe", in which they write about the power and force of the new German radio technology (Signal, March, No. 2, 1942). Goebbels was popularized by placing PA in public places and inexpensive radio receivers of Folksempfenger brand. These radio sets were in the nation secretly called "Goebbels muzzle", and they could have been purchased by families with average incomes and the effects of deliberate propagandamedia marketing campaigns were not missed, by the Nazis of course.

\section{Hitler's TV}

One medium that had just arrived was television and for many people the statement that reads:"... it is good that Hitler did not have television because he would have gotten the war" was only partly true. National-socialist state has experimented with "the miracle of the media", so that he was able to transmit images at a distance that at that time was on the verge of the possibility of science fiction. The Nazis were known for their quick and easy acceptance of innovations that would be of use to them and were in line with the principle of trying to establish television transmitters and develop a network of TV receivers.

Young German television was in its infancy and it enabled the Germans to watch direct broadcast which is quite a complex process but it leaves a good impact on the audience. In the thirties, Berlin had 11 public TV audiences in the jurisdiction of the 
German mail and Hitler and Goebbels were unusually interested in the possibilities of television in the transfer of Nazi speeches, films and documentaries and entertainment programs for the purpose of raising public morale. Thus, for example, was the television broadcast of the Olympics in Berlin in 1936 and it is considered that the sporting event was attended by about 150,000 people. German television stations continued broadcasting in the evening during the Second World War to 1943, when the allies destroyed the Berlin TV transmitter in the bombing.

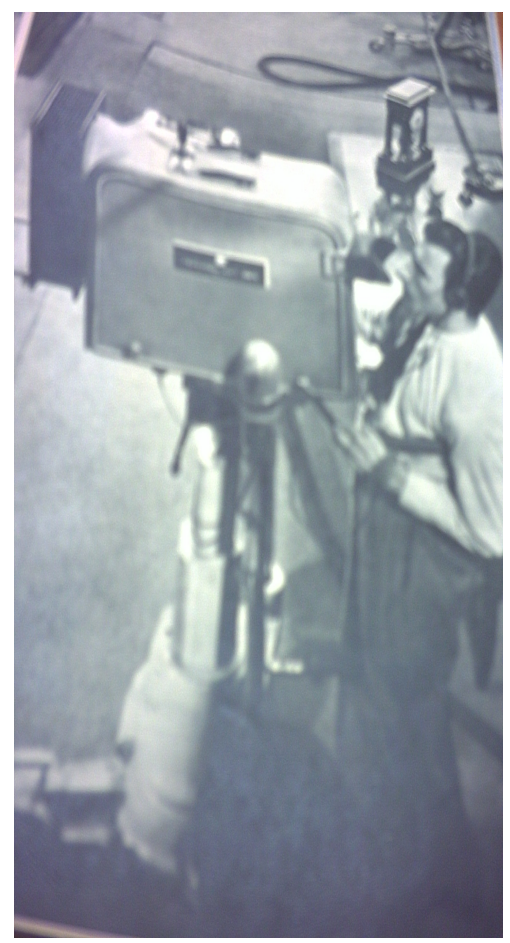

Nazi TV camera - Signal, March 1, 1942

As the war operations lead to the end of Nazism, television has become the ideal means of persuasion in the final victory of the Wehrmacht and the German television opened a theatre that had been reserved only for soldiers. About the new technological developments that the German technology reached, the press wrote: "The recently opened in Berlin, latest television theatre with a comprehensive program ... for a small TV-Television for the big race. Home appliances - such as cameras installed in all the Berlin hospitals can be used on a small area of historical, artistic and sporting events. It did not take the presence in person at the same time. New Berlin television theatre, which opened with "Heimlich Bratfahrt" (comedy VB) from Leo Lenz, television pictures showed the size of cinema. During the war, only soldiers can attend the performances." (Signal, March 1, 1942). 
Radio and television in the nazi media system

The Nazis created a media system that was equivalent to a totalitarian, brutal country that was based on violence and lies that were deliberately served to the public. Germans were supposed to convince the people of the alleged Jewish threat and the Communist conspiracy, the existence of "untermansch", or supermen and a series of untruths which were based on Hitler's regime. Having brought the media to the level of ordinary repeater of propaganda slogans, Goebbels was able to set standards for the dissemination of untruths and lies through the media, to which all subsequent dictators aspired. Complete media blockade and uniformity in reporting, "adorned" the German media in real-time Nazism, and it is difficult to speak about journalism work in such conditions. Journalists were seen as obedient soldiers who were to listen and write in accordance with the Nazi ideology that saw the media as one of the tools to govern the masses.

\section{Sources and literature}

[1] Kershaw lan, (2004.), Hitler 1889-1936, London, Penguin Books Ltd.

[2] Knopp Gvido, (2009.), Hitler's Henchmen, Phoenix Mil, Sutton Publishing Linited.

[3] Knopp Gvido (1998), Hitler's Kreiger, Munchen, Bertelsmann Verlag.

[4] Manvell Roger and Fraenkel Heinrich (1960), Doctor Goebbels: His Life and Death, New York, Simon and Schuster.

[5] Hohne Heinz (2000), The Order of the Deaths Head, The Story of Hitler's SS, London, Penguin Books Ltd.

[6] Haffner Sebastian, (2004), Geschichte eines Deutschen Die Erinnerungen 1914-1933, Stuttgart-Munchen, Deutsches Verlags-Anstalt GmbH. Book.

[7] Shirer L. William (1977.), The Rise and Fall of the Thirs Reich, New York, A Fawcett Crest

[8] Signal, a magazine published by the German Wehrmacht from 1940 through 1945

[9] Snyder L. Louis (1998.), Encyclopaedia of the Third Reich, Hertfordshire, Wordsworth Editions Limited

[10] Steinbauer Werner (1948.), Joseph Goebbels: Damond oder Diktatur, Stuttgart, Union Deutsche Verlagsgesellschaft. 